\title{
Teaching Web Design in Journalism and Mass Communications Programs: Integration, Judgment and Perspective
}

\author{
Cindy Royal \\ Doctoral Student \\ The University of Texas at Austin \\ clroyal@mail.utexas.edu \\ Submitted to: \\ "Expanding Convergence: Media Use in a Changing Information Environment" \\ May 16, 2003
}




\begin{abstract}
:
The Internet is being implemented for many educational and academic purposes, and departments of journalism are no exception in integrating technology into the curriculum. The presence of the Internet in education is causing many educators to reconsider, reevaluate, and modify their teaching methods to meet the needs of a new media environment. But this presents many challenges. Should the focus be on theory or practice? This paper is a case study of a Web Publishing course that covers the basic skills of Web design, graphics, animation, and multimedia, and how it has evolved over time to focus on integration, judgment, and perspective.
\end{abstract}




\section{Introduction}

The Internet is being implemented for many educational and academic purposes, and departments of journalism are no exception in integrating technology into the curriculum. Traditional courses in journalism use the Internet to supplement instruction, many courses use Web sites to communicate syllabi and lessons, and Internet technologies are being used to deliver distance education. (Sutherland and Stewart, 1999) New media is being studied critically and theoretically in disciplines as varied as communications, liberal arts, business, law, policy, and computer science. Web publishing courses, teaching students to create and maintain Web pages, are a popular course offering in many disciplines as well. The presence of the Internet in education is causing many educators to reconsider, reevaluate, and modify their teaching methods to meet the needs of a new media environment.

But this presents many challenges. A long-standing debate in academia has argued the role of a university education. There are those that opt for the theoretical model, in which the focus is on critical and intellectual skills. Conversely, others feel students are best served by teaching skills necessary to perform in a given profession. And there are a variety of approaches that take the middle ground and try to balance the teaching of skills and theory in a manner that is both meaningful and relevant to students.

The new media environment adds to this pressure. In a curriculum that is already full, with this precarious balance of skills and theory stretching existing resources, how does a program implement a new area of study around hypertexts, multimedia, interactivity, Web design, Internet searching, and online credibility? Journalism departments at major universities around the country are grappling with the ways in which new media can be integrated into their existing curricula or developed as a unique sequence. In some cases, programs are reconsidering their entire approach to media around the idea of convergence, or the melding of media, in which students are exposed to skills that are relevant across media types. (Friedland and Webb, 1996) 
Regardless of the approach to the multimedia environment, university journalism departments are offering Web design skills in a variety of courses. A Web search of some journalism departments' course offerings revealed the following titles: Web Publishing (The University of Texas), Web Design (University of Miami), Cybercasting and Cyberpublishing (University of North Carolina), Online Journalism (University of Missouri), or Website Design and Development (Virginia Commonwealth University). Skills in these classes include Hypertext Markup Language (HTML) or Extensible Hypertext Markup Language (XHTML) coding, Web editing software, graphic design, animation, and audio and video editing. But, like other journalism skills -- interviewing, copyediting, news writing, and reporting -- what is the role of the university beyond teaching skills necessary for employment? Is there a responsibility beyond teaching a specific skill set that can aid in providing students with judgment and perspective on their environment?

Many community colleges and technical schools teach Web Design in their curriculum. Topics in these classes are similar to those mentioned above as being taught at the university level. For example, in the Webmaster certification program of a community college in central Texas, the curriculum includes courses in Web authoring with XHTML, Macromedia Dreamweaver (a Web editing software package), Adobe Photoshop (a graphics design and photo manipulations package), and Macromedia Flash (a graphical Web design environment package), among others in Web programming and database design. The focus in this curriculum is in-depth comprehension of individual Web design skills or applications. These courses are offered discretely over several semesters. By offering classes in this manner, it is difficult for a curriculum to integrate learning across skills, programs, and platforms. The opportunity to integrate what is learned comes in a capstone practicum at the end of the program in which students are expected to draw on these skills in an applied project. What this program and others like it do not offer is a means to demonstrate how skills build upon one another and how to make appropriate judgments across skills when embarking on a Web 
design project. Most importantly, these programs do not offer a perspective on the new media environment that can influence not only design decisions, but can offer a critical and theoretical understanding of multimedia issues. While teaching skills in this manner may not be the mission of community or technical schools, I argue that the university is well suited for integrating skills, judgment and perspective into Web design courses.

This paper deals with one such course offered in a journalism program at a large university in central Texas. The Web Publishing course that covers the basic skills of Web design, graphics, animation, and multimedia has evolved over time to focus on the necessary critical and intellectual approaches that are missing from many Web design curricula. 


\section{Relevant Scholarship}

As mentioned above, a long-standing debate exists around defining the role of the university. Philosophers have considered the influence of nature, society, and collaboration in the educational process. John Dewey, a pragmatic educational theorist in the late $19^{\text {th }}$ and early $20^{\text {th }}$ century, was an advocate of informal education. He defined education as proceeding "by the participation of the individual in the social consciousness of the race." (Dewey, 1897) He believed that a student learned from social situations with a focus on both the psychological as well as the sociological elements of the educational process, and that the role of educators was that of stimulating intellectual and critical thought.

Brazilian educator Paulo Freire's theories of learning included a critical consciousness about the world. (Freire, 1993) He believed that a pedagogy of literacy should be used to illuminate the world regarding power, oppression, and marginalization, and to cause students to questions their own social and historical positions. Part of his teaching philosophy includes a dialogic exchange between educators and students where both learn and both create meaning.

Recently, the presence of commercial interests that fund departments, programs, computer labs, and scholarships has developed into an environment that has caused the university to reconsider the balance between intellectual thought and practical knowledge. The university struggles to meet the needs of students, constituents, and community by juggling new teaching methods, technologies, and a changing cultural, social, and political climate. It must balance the practical application of knowledge in real world settings with the ability to critique events in the surrounding environment. Researchers have analyzed this tension between corporate interests and academic goals, as well as how the changing needs of society will influence university approaches to education. (Duderstadt, 2000; Sculley, 1997; Brown, 1991) And some have resolved the theory versus practice dichotomy with a social learning theory approach in which a community of practice is developed to create meaning and identity within the practice environment. (Wenger, 1998) 
The role of computers in education is another point of academic contention. Using computer technology in learning, literacy, and literary environments has been both lauded (Rheingold, 1993; Spender, 1995; Negroponte, 1995) and criticized (Stoll, 1995; Birketts, 1994; Postman, 1985). Michael Apple reflected on the role of technology in education by tasking educators "to make sure that when it [technology] enters the classroom it is there for politically, economically, and educationally wise reasons." (Apple, 1991) Cynthia Selfe discussed the narratives around technological change and education and found it easy (particularly for Americans) to believe that technological change can lead to productive social change. She cautioned that an exclusive focus on positive change could distract educators from recognizing how existing social forces work to resist technological change. "Within the English studies programs that we design and administer, and participate in, we place everyone in jeopardy if we limit our understanding of technology and change to one dimension, if we teach students only one part of this complicated picture." (Selfe, 1999: 322) She continued by stating that a good English curriculum will "educate students robustly and intellectually rather than narrowly or vocationally" and will focus on educating students to be critically informed rather than technical experts.

The two-attitude debate about technology, as either utopia or downfall, is mirrored in the debate over technological determinism (Benjamin, 1968; McLuhan, 1994) and social construction of technology (Williams, 1975; Latour, 1994). Bolter and Grusin recommended a balanced approach to resolving these tensions as well. "In an effort to avoid both technological determinism and determined technology, we propose to treat social forces and technical forms as two aspects of the same phenomenon: to explore digital technologies themselves as hybrids of technical, material, social, and economic factors." (Bolter and Grusin, 2000: 75)

In a separate essay, Bolter identified the challenges to literacy that computer technology, specifically in regard to visual communication, imposed. He identified that the first challenge was to the traditional definitions of what is considered good reading and writing. Within 
hypertext, the system is challenged to give students new skills in understanding potential linkages and paths of their own creation. But he stated that these approaches may not require a break from traditional learning in which critical reading and making of meaning as well as the focus on collaborative learning have been articulated as values of a good education. (Bolter, 1998)

Other approaches to literacy have mirrored these dichotomies. The idea of shared cultural symbols versus a postmodern approach to racial and ethnic sensitivity has led to a reconsideration of the nature of community. And the great divide narrative that separates literary and oral cultures (Ong, 1982; Havelock, 1986) has led to the privileging of print media. What these debates have in common is attention to the connections between literacy, education, and social and cultural change. (Daniell, 1999)

Finally, Landow, in his early discussions of hypertext, recommended the reconfiguring of student, educator, learning environment, assignments, and the canon in order to deal with the nuances of new media. He said that the nature of hypertext "redefines the role of instructors by transferring some of their power and authority to students." He further added that hypertext can support the melding of multiple disciplines and defined hypertext with the qualities of "connectivity, preservation, and accessibility" which make it a valuable teaching resource. In discussing the reconfigured student, Landow focused on critical thinking and providing the student with a means of learning not just about factual information, but what to do with that information when one has acquired it. Finally, Landow stated that assignments must support an approach to critical thinking and must allow the student to acquire skills beyond technical proficiency. (Landow, 1992)

With the increased emphasis on corporate presence and questions regarding emphasis, schools and departments of journalism struggle with the extent to which they teach skills in a "trade school" manner as opposed to intellectually teaching theory, concepts, and critical analysis. In 2002, the prestigious graduate program at the Columbia School of Journalism 
suspended its search for a new dean until it could further comprehend the role that a graduate education in journalism should play. The president of Columbia University, Lee Bollinger, wanted the school to be more "intellectually based." He stated, "It is more important to leave the teaching of the on-the-job skills to [the workplace]... There's a role at the university for skills training, but it should not be the dominant position." (From Walsh \& Fogg, 2002) In April 2003, Bollinger hired Nicholas Lemann, a noted journalist and author, who has analyzed issues of race and inequality. The qualities that Bollinger articulated in crafting his vision of journalism education included:

- teaching the craft of writing and reporting,

- developing the "intellectual ability to deal with new situations as knowledge and working conditions shift over time,"

- giving students a background in the history of journalism,

- and creating in students "an identity as a professional, which includes the moral and ethical standards that should guide professional behavior." (Casselman, 2003)

In his initial press statement, Lemann agreed with Bollinger's goals, saying he hoped to move the discussion beyond the debate between those who believe journalism schools should teach only the craft, and those who think they should teach only the theory of journalism. "You should add to graduate journalism education something more like graduate education in other fields." He further stated that journalists needed to learn not only basic skills, but must also possess a broader intellectual framework in which to apply those skills. (Casselman, 2003)

Others have questioned whether journalism should be considered a profession like medicine or law, with a shared set of principles and standards, a trade that should focus on the acquisition of skills, or something in between that offers a multidisciplinary approach to political, social, and cultural issues. De Burgh stated an education based on critical thinking is consistent with preparation for a career in journalism. "Journalism studies can provide such an education partly because 'all human life is there' and partly because, in the learning of it, the vaunted divide between the academic and the practical is a false dichotomy... As if that were not enough, there has never been a greater need for journalists with the tools and the education 
which will equip them to be the tribunes of the people. It is the academic discipline of today. And skills are not enough." (de Burgh, 2003)

If skills, theory, and critical thinking must be taught in concert with one another, then exactly what skills should be the emphasis in a journalism education? Several scholars have addressed the role of technology in the journalism curriculum. Huesca identified hypertext as the challenge to the "canon of unity" with its fluidity, multiple perspectives, and fragmentation and relationships between readers and writers. (Huesca, 2000) He proposed a dramatic change to journalism curricula to accommodate these challenges, rather than the additive approach that is being taken in many programs in which extra courses or multimedia sequences are add-ons to the course offerings. He outlined a class in which " the attitude was not one of mastery of skills and understanding, but one of exposure to key ideas and practices and exploration of new forms and technologies. " The results from this course showed that students were more engaged and challenged and felt that they had been stimulated to think intellectually and creatively.

Additional studies that have analyzed the integration of skills and theory include the requirements of arts and science classes in journalism curricula (Ryan and Switzer, 2001), teaching diversity in mass communication courses (Lasora, 2002), using cognitive theory or creativity in teaching graphics design courses (Cookman, 1998; Coleman \& Colbert, 2001), and infusing the teaching of Magazine design with a sensitivity to cultural issues around image and representation (Durham, 1998).

Given these varied approaches to the nature and purpose of a journalism education, how does one course in Web design meet the intellectual as well as the skills needs of students? What follows is a case study of the Web Publishing course offered in the School of Journalism at The University of Texas in which Web design skills are integrated with lessons and projects that complement and support judgment and perspective on the new media 
Teaching Web Design in Journalism and Mass Communications Programs: Integration, Judgment and Perspective

environment. The purpose of this study is to provide practical applications of educational theory, supported by course evaluation results and student comments over time.

\section{Background}

In 1998, the journalism department began offering a course in Multimedia Publishing. The primary goal of the course was to give students practical experience in designing and maintaining the department's Web site. The initial focus of the course was on beginning HTML skills, usage of Netscape Composer, a free Web editor included with the Netscape browser, and beginning photo and graphic manipulation with Adobe Photoshop. The course was taught in a journalism computer design lab in which 17 Power Mac computers were available with the above-mentioned software. The classroom was equipped with LCD projector to facilitate instruction and examples from an instructor's computer station. Student evaluation was based on work done for the Web site and other student Web design projects. No tests or exams were used with the emphasis on creative and accurate work that functioned properly.

During the fall of 2000 , as a doctoral student in the program, I was assigned as teaching assistant for what had been renamed the Web Publishing class. During that year, I was able to observe student learning and motivation in working on assigned responsibilities for the Journalism site. Additionally, I observed that the progression of Web design skills and applications was outpacing the resources that our computer lab provided.

In the fall of 2001, I was asked to instruct the Web Publishing course. At the same time, the computer lab had been upgraded to G4 Macintosh computers with updated application software by Macromedia, Adobe, and Apple. This allowed the course to be updated to include more advanced Web design topics. The G4 system also allowed the connection of USB and Firewire devices, thus paving the way for the introduction of multimedia capture and editing.

A new professionally designed Web site was unveiled for the department's web site, thus relinquishing the class from the day- to-day responsibilities of updating the site. I was 
tasked with designing a new syllabus, lessons, and projects that would incorporate the new programs and skills required in the multimedia landscape. But I also felt strongly that it was important to infuse the course with critical and theoretical issues around technology. And, over time, it became apparent that each skill -- be it HTML coding, graphic manipulation, animation, or multimedia editing -- did not stand alone, but rather slowly and consistently built upon one other in a manner that provided a broad, yet integrated approach to Web design. The course evolved in direct contrast to the deep and discrete approach to Web skills offered at a community or technical college described above.

\section{Case Study}

In the Web Publishing class, the curriculum was designed with a three-pronged approach, covering integration of skills, judgment regarding decisions around design and content, and perspective on the new media environment. This approach allows the class to cover a variety of skills, issues and concepts within the confines of a single semester. The goal is for students to emerge with a broad and integrated skill set, analytical and critical skills, as well as a strong perspective on issues around new media. The varied, yet integrated, approaches along with example exercise and projects are described below.

\section{Integration of skills}

The first and foremost area of the course is the teaching of Web design skills. In most cases, this is the students' first experience with Web-related concepts, but many come to the class having taken print design courses. The course begins with an overview of HTML and, more recently, XHTML concepts. Students need an understanding of these concepts because these skills encompass the foundation of all Web development and design. Even with the advent of Web editing programs, in order for the student to feel he/she has the maximum control over the development environment, one must be able to understand and interpret the underlying 
code. This perspective also provides an understanding of how browser's work and why Web sites might look differently across different platforms.

Beyond HTML skills, the class progresses with the inclusion of web editing with Macromedia Dreamweaver, graphic design with Adobe Photoshop, gif animation with Macromedia Fireworks, advanced animation with Macromedia Flash, and multimedia editing with Peak and iMovie. Lessons are created to highlight the features of each program. Generally, the class spends two weeks on a particular program with the ultimate goal of the module to demonstrate the skill by implementing a project. Projects are designed to highlight the new skill, but also to integrate all the previous concepts learned up to that point. For example, the first project requires students to use HTML only to design a simple, autobiographical Web site. The second project requires the usage of Dreamweaver and Photoshop to create a more advanced site about a hobby or organization. The usage of Cascading Stylesheets is introduced at this point. The third project requires students to redesign a Web site, but the requirement of gif animation is added. Each project stretches the skills a little more, while still honing skills gained in previous assignments. The final project of the semester is a multimedia, reporting project that integrates all skills learned in a story-telling format on a topic of the students' choice. Students are able to use a variety of media types, design their own graphics and animations, and include any type of content that they accumulate.

Another area related to skills is the focus on Web design in addition to purely technical skills. The focus in each module is on relevant design techniques like navigation, accessibility, layout, typography, and functionality. Skills are taught in regard to how they can support these concepts. For example, a lesson on cascading stylesheets points out that the concept of proximity of headings to related paragraphs (or keeping related information close to its heading) can be achieved through the HTML heading tags $(\langle\mathrm{h} 1\rangle,\langle\mathrm{h} 2\rangle$, etc.) by adjusting the stylesheet for a particular heading tag's margins. (See Figure 1). While the technical aspects and benefits 
of using stylesheets are illustrated with this lesson, the important design aspect is also highlighted.

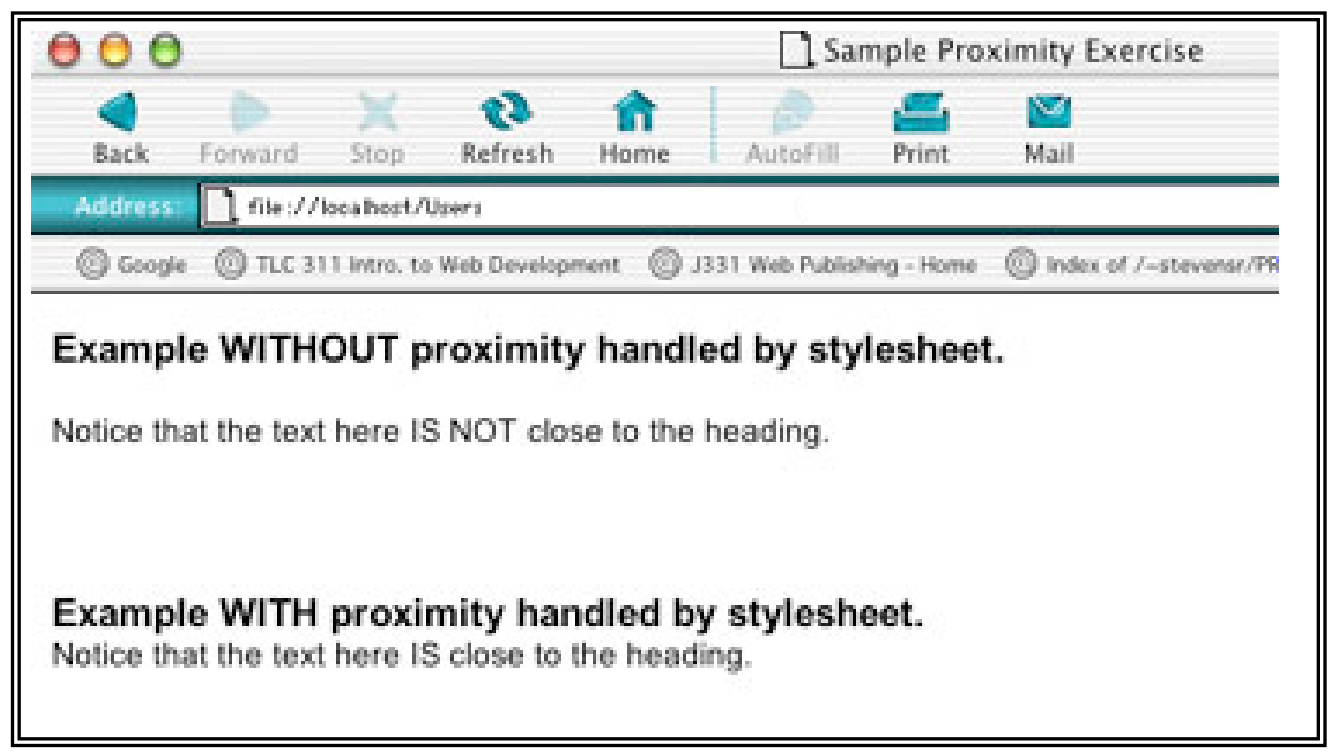

\section{Figure 1}

Another goal of the skills aspect of the course has to do with the importance of communicating skills in a manner that is not platform or program specific. Students should leave the class with an understanding of industry standards and what they are likely to encounter in practice, but should also have an understanding of how these skills can be applied to different versions of the same software, competitive programs, or as the environment evolves. This is handled by encouraging students to test their designs in other computer labs and by explaining features in regard to their general purpose as opposed to their specific functionality in a software program. For example, it is not uncommon that computer labs on campus might be hosting different versions of the same software package. The migration from Flash 5 , which is available in the journalism labs, and Flash MX, which is becoming available across campus, requires students to comprehend not only the interface changes, but the challenges in regard to fonts and feature incompatibilities between environments. 


\section{Judgment}

Related to the integration of skills is the concept of judgment. By teaching Web design in an integrated rather than discrete manner, one is able to gain the proper judgment necessary to make decisions about Web design issues for future projects. Rather than focusing on recipes for achieving certain effects, students are given skills in determining what programs and techniques to use to gain desired effects that influence not only design, but content and accessibility of their projects. An example of this is in our discussions of the different types of animations available on the Web. We use Macromedia Fireworks to create GIF animations, a simple type of animation whose format is supported by most standard browsers. But, when we move on to Flash animation, we are careful to discuss the pros and cons of using this file format for animations. Flash requires that the users' computers have the proper Flash plug-in, so a site designed with Flash should utilize the more extensive features of the program, rather than requiring the user to download a player to see an animation that could easily have been achieved through the GIF format. Additionally, questions of accessibility revolve around the appropriate usage of animation and ways in which it can be more accessible for those with usability impairments (i.e. adding alt tags to images, not embedding large blocks of text in images, etc.)

Judgment is also highlighted in sessions that illustrate the issue of credibility on the Web. This is of particular importance in the area of online journalism, but also to students as users of Web content for personal, professional, and academic purposes. This concept is illustrated first in a credibility lesson. A discussion on Web credibility is used to point out ways in which students can use critical skills to assess a Web site's credibility, accuracy, or objectivity. A checklist of the items from the discussion is created (see Figure 2), with credibility features being separated into three areas: content, authority, and presentation. Students are split into three groups, one for each area, and are asked to review the same site (selected by the instructor) for their assigned area. After 15 minutes of reviewing and discussing the site in 
groups, the students are asked to come together to reveal their findings to the class. After this group exercise, the students' are assigned a credibility project in which they must analyze a site of their own choosing on all three areas of credibility, and submit a short paper with their results. A follow up project has students redesigning an online journalism site home page, and part of the redesign focuses on aspects of the layout and presentation that can detract from or improve credibility, like including the date updated, a way to contact the Web designer, links to outside sources, or discussion of credentials. Reviewing other online journalism sites and discussing the features of sites like CNN.com, NYtimes.com, The Drudge Report, and Salon helps to illustrate how the presentation features influence our impression of credibility. Together, the credibility lesson, written assignment, and redesign project support a variety of practical, conceptual, collaborative, and critical skills and resulted in integration and judgment on the part of the students regarding the credibility of Web content. 


\section{Web Publishing and Development}

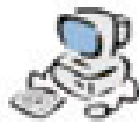

\section{Evaluation Checklist}

Consider the following questions when evaluating the content of a Web sile. Keep in mind that not all shes will have all the features being evaluated and that new developments in the Wob may require new rules or modfications of current rules in fuhure evaluations.

\section{Content}

1. Is the page complete or still under construction?

2. What is the title of the page?

3. When was it created, last updated?

4. Who is the audience, is there any obvious bias or slant to the information?

5. Are other sources of information available from the ste? Are the links for the site internal or external sources? Do they all work properly?

6. Do outside sources support the information? (journal articles, scholarly malerial, other news sources)

\section{Authority}

1. Who crealed the page? What are hisher credentials?

2. Is there a means to contact the author? Email, phone, address? Discussion forums or other interactivity?

3. What are their associations or affiliations? Does the site make that clear?

4. Who is sponsoring the site? is that clearly stated?

5. What does domain name tell you about the site? is it a .com, gov, edu, personal Web Page?

6. Can you backtrack in the url to get more information about the sile or author?

7. Can you tell if the site is accurate? Are there references to cutside sources of the information?

8. Is there a non-Web version of the site? If not, this is not necessarily a detriment but can add of detract from credbility based on the reputation of the print medium.

\section{Presentation}

1. Is the site prolessional looking?

2. Is if free of grammar, spelling and punctuation problems? is the writing style appropriate for the topic?

3. Is the format of the site meaningtul and easy to use? Are there appropriate headings? is navigation useful?

4. How do images and sounds work on the site? How do they support the content? Could they have been ediled?

5. How did you find the site? Consider how the search engine works? For example. Alta Vista searches meta tags that are assigned by the author in the code and Yahoo uses a registration by author.

6. Can you tell if news, ediforial, and advertisements have separate presentations on the sibe?

7. Look at the source code of the sile. Is there amything in it that influences your improssion? Mota tags, datos, comments, otc.

*Compled from Janet E. Alexander and Marsha A. Tate, Wob Widom: How to Evaluate and Create intormanon Qualiy on the Wob. Lawrence Eriboum Assodates. March 1909

\section{Figure 2}




\section{Perspective}

The most important aspect of the class, in my opinion, is the emphasis placed on covering the variety of perspectives in which new media and the Internet impact our lives. This is accomplished in many ways, and like the variety of skills that are taught, is integrated into all lessons and project work, so as to not delineate these topics as separate in the Web design environment. One way in which this is instituted from the beginning of the course, is the requirement on each class period that one student provide a news item about the Internet or technology for a short discussion at the beginning of class. This starts the class with a topic that is of interest to and selected by a student, and has each session opening with voices other than that of the instructor. The ensuing discussions around the topics are usually very lively and interesting, and it is a challenge to keep them to a five- to ten- minute format. Unlike many undergraduate classes where it can be difficult to enlist student participation, this method encourages student participation in an environment that is comfortable and informal. By allowing the students to select the topic, they are in control of a portion of the agenda of the class. Many topics, like music swapping, online dating, cloning, Internet sales tax, etc. are revisited throughout the semester, either in other student presentations or projects, or in planned modules on cyberlaw and social issues.

Using outside resources can be a strong supplement to classroom experiences if used appropriately. At the beginning of the semester, I show a PBS video on the history of the Internet and Web (Nerds 2.0.1, 2000) to set the stage for the rest of the class. The strength of the video is that students learn about the creation of the technologies from the people who were directly involved, and they are able to gain a sense of the origin and evolution of the technology. Many are surprised that the Internet was not initially developed for commercial purposes or that it was not designed to decentralize communications in a state of nuclear attack as a result of the Cold War. Ensuing discussions and postings on the Web site discussion board point to the realization that the Internet is a fairly new technology with both opportunities and challenges. 
Discussions of the demographics of early innovators of the Internet as educated, white males also set the stage for future discussions on the digital divide and representations of gender, race, and class online. Later in the semester, a PBS video on the digital divide (Virtual Diversity, 2000 is used to generate a discussion of students' own experiences with technology and the cultural factors that might have influenced their participation.

Other outside resources, like guest speakers, can also be a strong addition to class experiences. I try to host at least two speakers each semester to represent careers in Web design, creative Web projects, or Web entities that are driving important developments in the field. Integrating several of these concepts into one can be challenging, but this past semester we hosted a Web designer from a local non-profit that provides science and technology training to young girls. This speaker represented the function of a Webmaster, and as a female, showed a woman in a career traditionally held by males. Also, by being part of a non-profit focused on girls and technology, discussions around those issues were incorporated into her session. Other speakers have included the CEO of Audio Galaxy, a Napster-like musicswapping site, and the proprietor of the Austin Museum of Digital Art (AMODA).

Formal lessons are planned throughout the semester to integrate items of social perspective with skills training. In addition to the modules on the history of the Internet and Web and the credibility lessons, modules on cyberlaw, digital divide, and e-commerce are introduced to prepare students for their Flash project dealing with an issue on the social impact of the Internet. Classroom discussions focus on the complexity of these issues and provide students with links to resources for delving more deeply into the topics. A brainstorming exercise is used to help students generate ideas for projects and understand the broad-reaching aspects of the Internet as a social medium, allowing them to express issues that are of specific concern to them. Students select their topics, and in the past, projects have illustrated the issues of email communication, online dating, virtual travel, hackers, digital divide issues both locally and globally, online gambling, online political activism, and cybersex and online pornography, 
among others. These projects have typically been very creative and served to demonstrate students' ability to utilize the features of Flash to tell a story or explain an issue, as well as to comprehend and explore the topic of their choice.

The final project of the class is a multimedia reporting assignment that allows students to create an extensive site in which they chose the topics, technologies, and resources in telling an extensive story. Final projects have included local and community event coverage, campus life, religious and political activities, and important social concerns like depression, rape awareness, and body image. This project is the culmination of the three approaches of the course: skills integration, judgment, and perspective.

\section{Results}

Since implementing the changes to the Web Publishing course in Fall 2001, demand for the course has increased, with long waiting lists each semester. Course evaluation scores increased due to the implementation of recent technology, the purchase of new equipment, and the emphasis on integration, judgment, and perspective in course topics and discussions (see Figure 3). While the class has a heavy workload associated with it, students rarely express displeasure in that regard. Student comments from course evaluations over the past three semesters have dealt with the applicability of topics to their future careers and general student enjoyment of the experience. Selected comments include:

- "I learned so much in this class that I can use in the real world."

- "This is probably the single most valuable class I have taken yet. There should be more classes like this."

- "I really enjoyed this class. I've learned so many valuable skills that I can apply in the real world. I liked the topics and the projects."

- "Excellent class, one of the most interesting I have ever taken."

- "I think this class has given me skills that will make me more marketable when I am trying to get a job."

- "This was, by far, one if not the best journalism classes I have taken at UT. There should be an Advanced Web Publishing class. I have learned so much and now have the ability to host my own Website. This class should be required."

- "... teaches many important Web skills and builds in the bigger picture on what this could all mean for society. 
- "This is an amazing class that should have a Part 2 for it. The content of the course is very useful and practical."

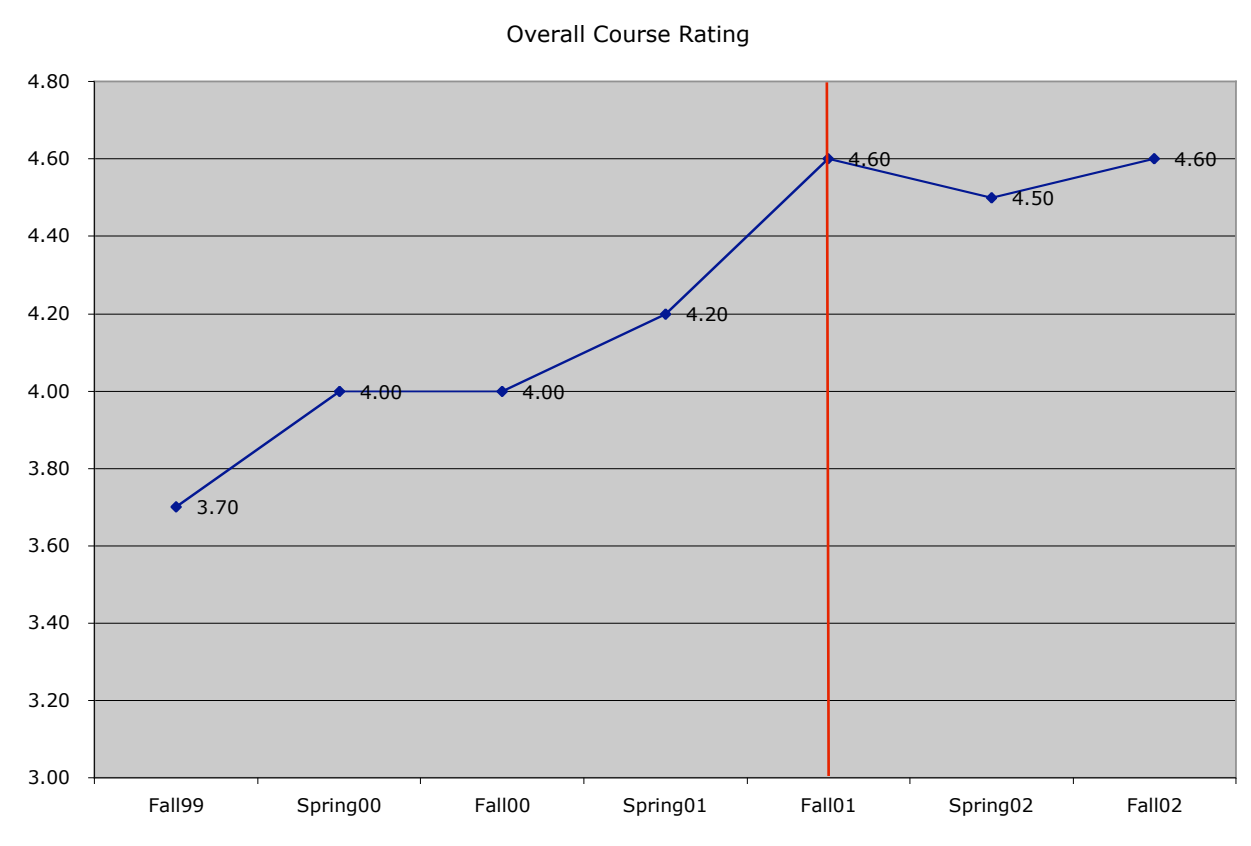

Figure 3

\section{Challenges}

The environment described above is not without its challenges. First, the classroom must be designed to allow students access to technologies for autonomous usage and directed study. In addition to the three-hour lecture time period per week, this course has an additional three-hour lab that is required. During the lab time, students work alone or receive assistance from the instructor. Encouraging an environment in which students can collaborate and learn from one another can often make for a hectic and sometimes loud classroom, but the instructor must be prepared to operate under these conditions. Additionally, a lab setting must also be able to support student discussion and interaction. In our lab, we accomplish this by having a center table that we use for coming together as a group. The computers are arranged in a circle around the periphery of the room. The center table made for informal discussion format and reduced the hierarchy of the traditional classroom format that is often characterized by rows of 
seating. An instructor's computer linked to a projector is at the front of the classroom to facilitate examples and to show student work.

The class moves very quickly. Students that were subject to frequent absences, either due to health problems, extracurricular activities, or just plain laziness, have had a difficult time keeping up with assignments. But those with regular attendance, while indicating that the workload was steep, have had no problems keeping up with course requirements and advancing skills and seem to enjoy the pace and challenge of the environment.

As an instructor, the class has been challenging from many perspectives. The instructor must possess advanced skills in each of the programs taught, must have strong troubleshooting abilities to help students that encounter problems, and must be able to understand the importance of judgment and perspective on teaching technology skills. In addition, the instructor must be prepared for any discussion topic and have a broad sense of the environment and knowledge of outside resources for follow up. If one day a student brings in an article on testing lab mice for cell phone radiation, and the next day the topic is someone using Ebay to auction a peanut butter sandwich, he/she must be able to lead the discussion and ask questions of the class to make the topic meaningful. The instructor must have a broad understanding of the business, technical, cultural, and social environment of technology, and knowledge of its specific application in the communications field.

The instructor must view the course as a learning environment, not only for students but also for himself/herself, and thus communicate that role to students, much like the environment supported by Freire's pedagogical approach. (Freire, 1993) Rather than being the sole imparter of knowledge, the instructor must illustrate to students the processes by which he/she accomplishes troubleshooting, seeks out additional information, or participates in self-study to advance knowledge of the field. It is not enough for the instructor to be able to admit that he/she does not know the answer to a student's question. The instructor must show the students the 
ways in which he/she searches for answers and how students can find the answers out for themselves.

There was no single textbook that could be used to facilitate teaching a class of this nature. Many books on discrete Web skills exist and some are very good at providing "how tos" and examples of Web Design. But requiring students to purchase four or five different texts to cover the range of skills in this class was an unreasonable and unnecessary expectation. I chose instead to develop my own skills lessons and to make them available in PDF format on the course Web site (http://journalism.utexas.edu/webpub). An additional text was used for Web Design concepts (Robin Williams \& John Tollett, The Non-Designer's Web Book, 2000), but the most effective teaching resources are the examples presented from different Web sites and our own daily use of technology. In addition, the class Web site not only serves as a learning resource, but as a showcase of Web design features covered in the course (see Figure 4).

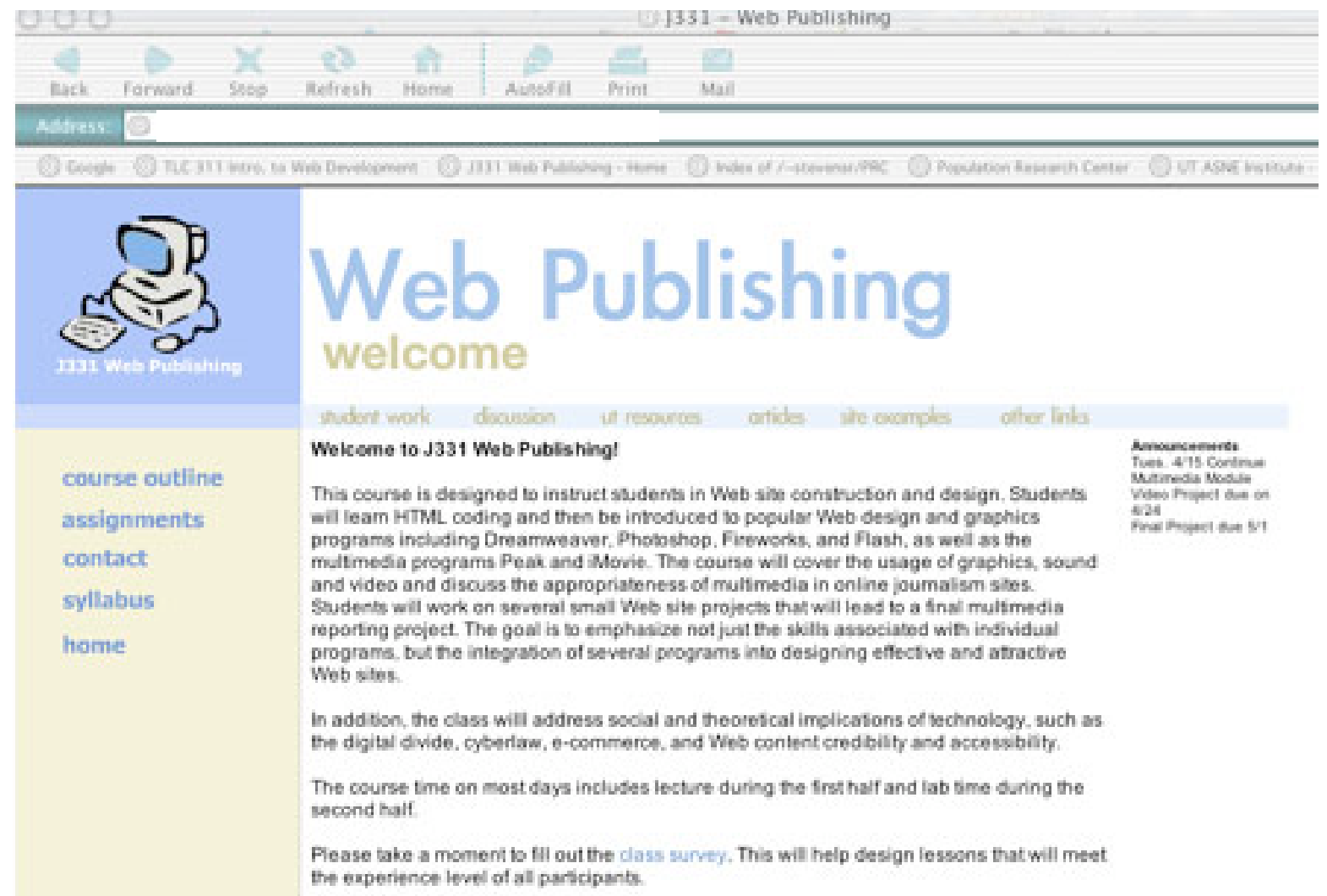

Figure 4 
Additional challenges exist around the changing nature of the technological environment. New media software packages are constantly being upgraded, and computer hardware must also be upgraded to keep pace with improvements in hardware and peripherals. For example, without the addition of Firewire on the new G4 Macs we had installed in our labs, we would not have been able to add video editing to our offering.

And as the technological environment changes, so must instructors and students be flexible in their ability to learn and apply previous knowledge to these new features. A recent issue of Journalism and Mass Communication Educator (Winter 2003) focused on the stresses that faculty and students face in implementing change caused by new technologies (Beam, Kim, and Voakes, 2003; Ogan \& Chung, 2003). Instructors must be able to mange stress and channel it by highlighting the challenge and dynamic nature of the new media environment. 


\section{Conclusion}

But with these challenges come vast opportunities for both students and educators. While the role of journalism departments might be, on the surface, to create journalism professionals, the area of new media can open up career opportunities and personal experiences that might have previously been unavailable, whether entering the journalism profession or another field. The ability to create, develop, and communicate via the Web is a great opportunity that presents students with responsibilities and challenges that must be considered. But teaching skills in a discrete manner without a focus on integration, judgment, and perspective in the new media environment will ultimately fail students who suddenly find their skills outdated, outmoded, or out of sync with the real world. Whether journalism programs create multimedia sequences, new majors, converge their media platforms, or explore other approaches, the teaching of Web design will continue to be an important skill in which to offer instruction. It is also a unique opportunity to impart other vital learning experiences, and this can be accomplished by integrating judgment and perspective throughout the course and Web curriculum.

Note: A video presentation of some of the teaching techniques illustrated in this paper is available to accompany presentations. 


\section{References}

Apple, Michael, "The New Technology: Is It Part of the Solution or Part of the Problem in Education?" ( 1991) in Literacy, Technology, and Society: Confronting the Issues, eds. Gail Hawisher and Cynthia Selfe, Prentice Hall, Saddle River, NJ (1997)

Benjamin, Walter, The work of art in the age of mechanical reproduction. In Hannah Arendt (Trans.), Illuminations (pp. 217-251). New York: Schocken Books (1968).

Birkerts, Sven, The Gutenberg Elegies: The Fate of Reading in an Electronic Age. Boston/London: Faber and Faber (1994).

Bolter, Jay David. "Hypertext and the question of visual literacy," In David Reinking, Michael C. McKenna, Linda D. Labbo, and Ronald D. Kieffer (Eds.), Handbook of literacy and technology: Transformations in a post typographic world, Mahwah, NJ: Lawrence Erlbaum. (1998): 3-14.

Bolter, Jay David, \& Grusin, Richard, Remediation: Understanding New Media, MIT Press (1999).

Brown, John Seely, "Research that Reinvents the Corporation," Harvard Business Review, Harvard Business School, Boston, MA, January - February (1991).

Casselman, Ben, "Lemann Selected to Be Next Journalism Dean: President Bollinger and Dean Lemann hope to lengthen the Master's program at the graduate school," Columbia Daily Spectator, April 16, 2003.

Coleman, Renita \& Colbert, Jan, "Grounding the teaching of design in creativity," Journalism and Mass Communication Educator, Summer (2001).

Cookman, Claude, "A Computer-based Graphics Course and Students' Cognitive Skills," Journalism and Mass Communication Educator, Autumn (1998): 37-49.

Daniell, Beth, "Narratives of literacy: Connecting composition to culture" College Composition and Communication 50, (1999): 393-410.

de Burgh, Hugo, “Skills are Not Enough,” Journalism 4(1) (2003): 95-112.

Dewey, John, "My Pedagogic Creed," First published in The School Journal, Volume LIV, Number 3, (January 16 (1897): pages 77-80.

Duderstadt, James J., "A Choice of Transformation for the 21st Century University," Chronicle of Higher Education, February 2000. II David Nobles, Digital Diploma Mills: The Automation of Higher Education, (http://www.firstmonday.dk/issues/issue3_1/noble/index.html), October (1997).

Durham, Meenakshi Gigi,“ Revolutionizing the Teaching of Magazine Design," Journalism and Mass Communication Educator, Spring (1998): 23-32.

Friedland, Lewis A. \& Webb, Sheila, "Incorporating Online Publishing into the Curriculum," Journalism and Mass Communication Educator, Autumn (1996): 54-65. 
Teaching Web Design in Journalism and Mass Communications Programs: Integration, Judgment and Perspective

Freire, Paulo, Education For Critical Consciousness. New York: Continuum (1993).

Havelock, Eric, The muse learns to write: Reflections on orality and literacy from antiquity to the present. New Haven: Yale University Press (1986).

Robert Huesca, "Reinventing Journalism Curricula for the Electronic Environment," Journalism and Mass Communication Educator, Summer (2000): 4-15.

Landow, George, Hypertext: The convergence of contemporary critical theory and technology. Baltimore: The Johns Hopkins University Press (1992).

Lasorsa, Dominic, "Diversity in Mass Communication Theory Courses," Journalism and Mass Communication Educator, Autumn (2002).

Latour, Bruno, Aramis, Harvard University Press, 1994.

McLuhan, Marshall.. Understanding media: The extensions of man. New York: McGraw-Hill. Reprint ed., Cambridge: MIT Press ([1964] 1994), http://heim.ifi.uio.no/ gisle/overload/mcluhan/umtoc.html.

Negroponte, Nicholas, Being Digital. Vintage Books, 1995.

Ong, Walter J, Orality and literacy: The technologizing of the word. London: Methuen (1982).

Postman, Neil, Amusing ourselves to death: Public discourse in the age of show business. New York: Penguin (1985).

Rheingold, Howard, The Virtual Community, available online http://www.rheingold.com/vc/book/ (1993).

Sculley, John, "The Relationship Between Business and Higher Education: A Perspective on the $21^{\text {st }}$ Century," in Literacy, Technology and Society, eds. Gail Hawisher and Cynthia Selfe, Prentice Hall, Saddle River, NJ, (1997).

Selfe, Cynthia, "Lest we think a revolution is a revolution: images of technology and the nature of change," In Gail E. Hawisher \& Cynthia L. Selfe (Eds.), Passions, pedagogies, and 21st century technologies, Urbana: NCTE, (1999): pp. 292-322.

Singer, Jane B., "Changes and Consistencies: Newspaper Journalists Contemplate Online Future," Newspaper Research Journal, Vol. 18, No. 1-2, Winter/Spring (1997): 2-18.

Spender, Dale, Nattering on the Net: Women, Power \& Cyberspace, Spinifex Press (1995).

Stoll, Clifford, Silicon Snake Oil: Second Thoughts on the Information Highway, Doubleday (1995).

Sutherland, Patrick J.; Stewart, Robert K. "How accredited programs use the world wide web," Journalism \& Mass Communication Educator. Vol. 54 (1999): 16-22. 
Switzer, Les \& Ryan, Michael, "The Acceptance of Critical-cultural Scholarship in Mass Communication Education," Journalism and Mass Communication Educator, Autumn (2002).

Switzer, Les \& Ryan, Michael, "Balancing arts and sciences, skills, and conceptual content," Journalism and Mass Communication Educator, Summer (2001).

Voakes, Paul S., Beam, Randal A., and Ogan, Christine, "The Impact of Technological Change on Journalism Education: A Survey of Faculty and Administrators," Journalism and Mass Communication Educator, Winter (2003): 318-334.

Walsh, Sharon \& Fogg, Peter, "Editing the Mission; Columbia's New President Wonders How a Journalism School Fits into a Research University," The Chronicle of Higher Education, August 9, 2002, p. 10.

Wenger, Etienne, Communities of Practice: Learning, Meaning and Identity, Cambridge University Press (1998).

Williams, Raymond, Television, Technology and Cultural Form, New York, Schocken Books (1975). 